\section{Applying Biogeochemistry to Identify the Geographic Origins of Insects-A Model Using Prostephanus truncatus}

Keywords: Intrinsic markers; Elemental profiling; Chemical screening; Inductively coupled plasma atomic emission spectrometry; Chemical geolocators; Elemental transfer; Larger grain borer

\section{Abstract}

The application of geochemical screening for tracking insects and other organisms is poorly understood. We explored multi-elemental profiles of an insect pest and its food from different locations in order to identify intrinsic markers of geographic origin.

ICP-AES screening was completed for soil, maize grains and Prostephanus truncatus of different geographic origin, with insects collected in the field or reared on maize under controlled conditions. Background level geochemical data are presented with concentrations of $\mathrm{Cu}, \mathrm{S}$ and $\mathrm{Sr}$ in maize, and $\mathrm{Al}, \mathrm{Ba}, \mathrm{Ca}, \mathrm{Fe}, \mathrm{S}, \mathrm{Si}, \mathrm{Sr}, \mathrm{Ti}$ and $\mathrm{Zn}$ in insects differing according to their origin, or that of their food. $\mathrm{Cu}, \mathrm{Fe}$ and $\mathrm{Zn}$ determinations of insects were $20,6.5$ and 11.5 times the concentrations of the maize they were reared on.

A Linear Discriminant Analysis (LDA) based on $\mathrm{Al}, \mathrm{Fe}, \mathrm{Sr}$ and $\mathrm{Zn}$ successfully assigned $78 \%$ of laboratory-reared $P$. truncatus and $94 \%$ of field-caught insects to their origin $(68 \%$ and $75 \%$ respectively after jacknifing). There was excellent discrimination between insects reared on maize from Guanajuato and Nuevo Léon, and Guanajuato and Michoacán, good separation between Sonora and Nuevo Léon but overlap for Sonora, Guanajuato and Michoacán, and Michoacán and Nuevo Léon. The same LDA for field-caught insects gave complete separation between Michoacán and Sonora, but some overlap between Michoacán and Nuevo Léon.

This robust ICP-AES technique successfully identified a combination of elements able to classify insects according to their origin. The model was restricted to elements showing a normal distribution but nonparametric tests suggest other elements may act as intrinsic markers. This shows the potential of atomic spectroscopy for remotely tracing insects and other biological materials, with applications including providing provenance data for species routinely captured for surveillance and to track natural enemies and wildlife.

\section{Abbreviations \\ ICP-AES: Inductively Coupled Plasma Atomic Emission Spectrometry; LGB: Larger Grain Borer; RBPH: Rice Brown Plant Hopper; PCA: Principal Components Analysis; LDA: Linear Discriminate Analysis; ICP-MS: Inductively Coupled Plasma Mass Spectrometry \\ Introduction \\ Many pests are routinely monitored for surveillance and to gain information about their distribution and range, as well as their population density and temporal fluctuations, in order to develop effective pest management models [1]. However, in most cases the origin of the individuals captured is not known [2,3] and since adult insects generally disperse away from their natal origin, more precise}

\section{Environmental Studies}

\author{
Tigar $\mathbf{B J}^{\mathbf{1}^{*}}$ and Hursthouse $\mathbf{A S}^{2}$ \\ ${ }^{1}$ School of Health Sciences, Liverpool Hope University, Hope Park, \\ Liverpool L16 9JD, UK \\ ${ }^{2}$ School of Science, University of the West of Scotland, Paisley \\ Campus, Paisley PAI 2BE, UK \\ *Address for Correspondence \\ Tigar BJ, School of Health Sciences, Liverpool Hope University, Hope \\ Park, Liverpool L16 9JD, UK, Tel: +44 (0)151 2912046; \\ E-mail: tigarb@hope.ac.uk \\ Submission: 04 November, 2015 \\ Accepted: 21 January, 2016 \\ Published: 27 January, 2016 \\ Copyright: (c) 2015 Tigar BJ, et al. This is an open access article \\ distributed under the Creative Commons Attribution License, which \\ permits unrestricted use, distribution, and reproduction in any medium, \\ provided the original work is properly cited.
}

location data about the sources of invasion of mobile species would improve management decisions and risk analyses, with potential applications for many other taxa and scenarios including migrant species of conservation interest that cross international boundaries.

Local and regional variations in background geochemistry result in distinct conditions which may profoundly influence flora and fauna [4]. Terrestrial invertebrates gain most of their elemental loading from food, with the highest chemical mobility into food webs occurring in nutrient-rich soils that typical occur in arable production systems [5]. Where geochemical data for insects exist, they suggest that the elemental profile of insects reflects the geochemistry of their environment, with anthropogenic activity likely to increase levels of toxic elements including heavy metals, and acting to reduce both invertebrate abundance and diversity [6,7]. Whilst many studies explore the fate of elevated levels of chemicals in invertebrate food webs [8-11] few have considered naturally-occurring, background level elemental loadings [12,13] or their application as intrinsic markers [3]. This is in contrast to the more widespread adoption of stable isotopes as assimilated markers obtained from background levels in food, that can be used to remotely trace animal dispersal and migration $[14,15]$.

There is some evidence that individual chemical elements and species interact in different ways although most studies consider the fate and behaviour of artificially elevated levels of heavy metals which are toxic. For example, some herbivorous insect larvae accumulate excess $\mathrm{Cd}, \mathrm{Cu}$ and $\mathrm{Zn}$ which are eliminated in their pupal exuviae, whilst elevated Cd levels slow down the developmental rate of predatory ground beetle larvae $[7,16]$. Rates of uptake and excretion in ground beetles suggest that $\mathrm{Ni}$ and $\mathrm{Cd}$ are rapidly accumulated, and then partially eliminated before reaching equilibrium at lower concentrations [17]. Specific effects caused by life-stage and sex have been shown in a few species and taxa, however most studies suggest that the chemical profile of insects achieves a steady state related to background elemental concentrations [18]. Therefore elements that can be detected via analytical screening methods are potential 
Citation: Tigar BJ, Hursthouse AS. Applying Biogeochemistry to Identify the Geographic Origins of Insects-A Model Using Prostephanus truncatus. J Environ Stud. 2016;2(1): 9.

ISSN: $2471-4879$

markers for tracing the origin of insects, particularly where rarer elements including heavy metals and trace elements show distinct geographic patterns of distribution.

Various atomic spectroscopy techniques are used to chemically screen biological materials, and their application to studies of pest dispersal and the human food chain were reviewed by Akey and Burns [19] and Beavington [20] respectively. These authors discuss the many factors influencing the choice of analytical technique, including specific elements, concentrations and material(s) to be tested, sensitivity and cost, as well as availability and personal preference. The range of atomic spectroscopy techniques currently available, provide powerful tools to reveal how environmental contamination moves between trophic levels and into ecosystems [21-24], and such methods are increasingly used to authenticate the provenance of high value foods such as honey, tea, rice and meat products based on the background geochemistry of their unique production systems [25-28], as well as for forensic investigations [29,30]. Entomological applications have included making multi-elemental chemoprints for a range of agricultural pests such as cereal aphids and moths associated with the soil chemistry of their larval food plant [31-35]. However, those elements best describing geographic origin were not fixed, and varied both with species and life stage for aphids [32,33,35], whilst polyphagous moths had highly variable elemental compositions suggesting that the identity of their larval host-plant was as important as soil geochemistry [31,34]. Dispersal by cotton boll weevils was traced by chemically characterising them and using trace elements as independent variables in multivariate models which assigned $100 \%$ weevils to one of three locations where they had been collected [36].

Recent studies show renewed and emerging interest in natural background variations in insect geochemistry and its applications. Such methods have benefitted from improved detection, sensitivity and computing power, and include examples based on trace elements and stable isotopes for wildlife management [37] and insect pest dispersal $[3,38]$. It has been suggested that multi-elemental and isotopic profiling could trace movement between natural reservoirs and infestations of Prostephanus truncatus [39], and for a closely related pest, Rhizopertha dominica, $\mathrm{Ca}, \mathrm{Na}, \mathrm{S}$ and $\mathrm{Zn}$ concentrations were associated with specific larval hosts and natal environments [40]. A model based on V, Mn, Fe, Mo, Se, Cd, Ce and Nd classified the majority of Rice Brown Plant Hoppers (RBPH) to their correct geographic origin [18] and multivariate models using combinations of trace elements and stable isotopes gave better determination of the origin of Helicoverpa armigera than models using the same factors individually [3].

This study explores background levels of elements and aims to identify a suite of markers to determine the geochemical origin of $P$. truncatus, a beetle which is considered to be highly invasive outside its native range [41]. The objective was to collect insects and their food from places that are geographically isolated and likely to exhibit a different geochemistry, maximising the likelihood of finding intrinsic markers for location. Insects were either collected in the field or reared under controlled conditions from egg to adult on maize collected from different locations, allowing the transfer of elements in a simple food chain to be followed.

ICP-AES was used to synchronously screen samples and chemically characterise soil, maize and $P$. truncatus for 20 elements: $\mathrm{Al}, \mathrm{B}, \mathrm{Ba}, \mathrm{Cd}, \mathrm{Cu}, \mathrm{Fe}, \mathrm{K}, \mathrm{Mg}, \mathrm{Mn}, \mathrm{Na}, \mathrm{Ni}, \mathrm{P}, \mathrm{S}, \mathrm{Si}, \mathrm{Sr}, \mathrm{Ti}, \mathrm{V}, \mathrm{Zn}$ and Zr. A multivariate Linear Discriminate Analysis (LDA) was used to classify laboratory-reared $P$. truncatus according to the origin of the maize they were reared on, and the model was applied to field-caught insects from some of the same locations.

We present a robust technique to identify a combination of elements able to determine the origin of this insect, and discuss those elements that are appropriate candidates for intrinsic markers. In addition to remotely tracking dispersal by species of economic interest particularly migratory species of biosecurity concern, multielemental profiling of biological materials has wider applications in ecology, environmental chemistry and natural resources management. This includes studying the movement of rare migratory species of conservation interest, and forensic investigations where the provenance of biological materials is unknown.

\section{Methods}

\section{Sample collection}

Mexican maize of known provenance was collected direct from producers in four federal states of Mexico: Nuevo Léon, Sonora, Michoacán and Guanajuato, with additional maize of unknown provenance purchased from two commercial suppliers to increase sources of elemental variation (the sources of maize are listed in S1). A total of 22 maize samples were subjected to chemical screening to characterize and examine differences in geochemistry.

Limited soil samples were collected from the top $5 \mathrm{~cm}$ of areas where the maize collected had been cultivated to investigate background soil geochemistry and to explore elemental transfer into a food web. Soil samples were bulked from around sampling locations as previously described [42] and were assumed to represent regularly turned over soil, therefore smoothing out any variability and reflecting the soil exposed to root systems. Data for soils were not sufficient for the same statistical scrutiny as maize and $P$. truncatus and are presented to allow comparison with other data on Mexican soils, supporting recent publications and interest in background plant and soil geochemistry [43].

Adult $P$. truncatus were caught in the field close to where maize was collected, although in some areas very few were captured. They were caught in flight traps baited with synthetic analogues of their aggregation pheromone (supplied by AgriSense BCS Ltd, Taffs Mead Rd, Treforest Industrial Estate, Glamorgan CF37 5SU, UK). Traps were emptied after $48 \mathrm{hrs}$ to catch those insects flying close by [44] which are most likely to be young adults dispersing from their natal origin nearby [45]. Insects were euthanized by freezing at $-5^{\circ} \mathrm{C}$.

\section{Elemental transfer from soil to maize, and maize to insects}

Maize from 12 sources was used in controlled feeding trials with $P$. truncatus, seven of these were paired with the soil in which they were grown in order to investigate elemental transfer between soil, maize and $P$. truncatus (see S1). All glassware used for insect cultures was decontaminated by soaking in Decon 90 (Fisher Scientific UK Ltd, Bishop Meadow Road, Loughborough, LE11 5RG, UK) for $\geq 6$ $h$, and then rinsed in Ultra High Purity (UHP) water ( $45 \mathrm{Ohm}$ ) and oven-dried. Stainless steel lids and mesh gauzes were hand-checked 
Citation: Tigar BJ, Hursthouse AS. Applying Biogeochemistry to Identify the Geographic Origins of Insects-A Model Using Prostephanus truncatus. J Environ Stud. 2016;2(1): 9.

ISSN: $2471-4879$

for loose metal, then heated in UHP water in an ultrasonic bath, oven-dried and sealed in plastic bags until required.

Three replicate honey jars containing $50 \mathrm{~g}$ of maize (types 1 to 12 , S1) were equilibrated overnight at $25 \pm 0.5^{\circ} \mathrm{C}$ and $75 \pm 1.5 \% \mathrm{rh}$. The next day, 20 P. truncatus adults were added and maintained at the same constant conditions throughout the experiment. After two weeks the founder beetles were extracted by hand, to ensure that all adult insects emerging 6 weeks later had been reared exclusively from egg to adult on maize from a single source. Insects were manually removed and euthanized by freezing at $-5{ }^{\circ} \mathrm{C}$ prior to chemical screening.

The soil samples provide background information on geochemistry and an insight into elemental transfer from soil to maize, and maize to $P$. truncatus reared on maize. The accumulation in terms of the increase in concentration between each trophic level for elements above DL in all three materials was expressed as a Mobility Index (MI) [46] where:

Mobility Index $=\frac{\text { Concentration of element }(\mathrm{mg} \mathrm{kg}-1) \text { in the receiving level }}{\text { Concentration of element }(\mathrm{mg} \mathrm{kg}-1) \text { in the source level }}$

\section{Sample preparation and ICP-AES assays}

The preparation and digestion of beetles, maize and soil follow previously described procedures for invertebrates, plants and soil [24], and included preparing bulk reference samples for all materials tested. Such methods provide results which have proven robust and sensitive enough for area wide surveys even where invertebrate concentrations were very low. Detection Limits (DL) were estimated from bulk reference samples of biological materials [24] ensuring we selected a population of positive data and elements that were consistently in that range, so minimising zero value influence.

To ensure reliability of determinations a pooled sample of 10 beetles was used for each analysis. Two replicates of each sample were

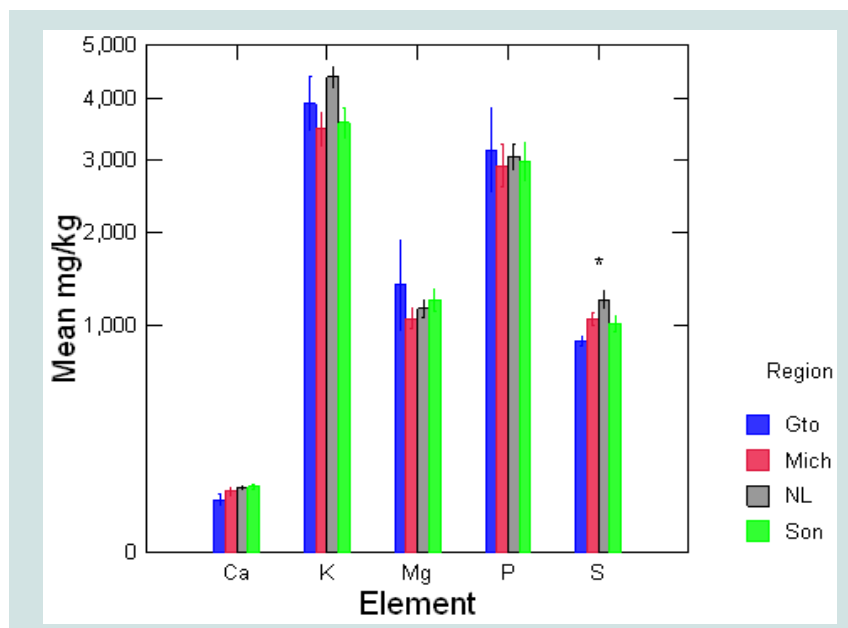

Figure 1: Mean $\mathrm{mg} / \mathrm{kg}$ of $\mathrm{Ca}, \mathrm{K}, \mathrm{Mg}, \mathrm{P}$ and $\mathrm{S}$ in maize from different regions (elements at high concentrations). Error bars are standard error around the mean at 0.68. Gto: Guanajuato; Mich: Michoacán; NL: Nuevo Léon; Son: Sonora.

Table 1: Mean $\mathrm{mg} / \mathrm{kg}$ and SD of elemental determinations for soil, maize and $P$. truncatus (DL indicates at or below Detection Limit).

\begin{tabular}{|c|c|c|c|c|c|c|c|c|}
\hline \multirow[b]{2}{*}{ Element } & \multicolumn{2}{|c|}{ Soil $(n=13)$} & \multicolumn{2}{|c|}{ Maize $(n=24)$} & \multicolumn{2}{|c|}{ Lab $P$. truncatus $(n=46)$} & \multicolumn{2}{|c|}{ Field $P$. truncatus $(\mathrm{n}=18)$} \\
\hline & Mean mg/kg & SD & Mean mg/kg & SD & Mean mg/kg & SD & Mean $\mathbf{m g} / \mathbf{k g}$ & SD \\
\hline $\mathrm{Al}$ & 41108 & 28303 & 22.17 & 15.11 & 95.33 & 63.37 & 41.67 & 7.37 \\
\hline B & 56.54 & 28.92 & 8.27 & 5.34 & 8.77 & 3.92 & 13.67 & 5.51 \\
\hline $\mathrm{Ba}$ & 203.00 & 65.11 & 8.67 & 19.18 & 7.92 & 16.36 & 26.33 & 43.02 \\
\hline $\mathrm{Ca}$ & 41173 & 32801 & 656.46 & 141.21 & 1268.06 & 622.71 & 1140.00 & 285.78 \\
\hline $\mathrm{Cr}$ & 37.15 & 25.76 & $\mathrm{DL}$ & $\mathrm{DL}$ & $\mathrm{DL}$ & $\mathrm{DL}$ & $\mathrm{DL}$ & $\mathrm{DL}$ \\
\hline $\mathrm{Cu}$ & 15.54 & 10.34 & 36.61 & 92.67 & 28.83 & 18.60 & 33.67 & 6.66 \\
\hline $\mathrm{Fe}$ & 26639 & 15860 & 104.15 & 35.15 & 168.67 & 63.32 & 126.67 & 11.59 \\
\hline K & 7436.85 & 5858.14 & 6721.30 & 943.68 & 6058.89 & 1549.05 & 6503.33 & 629.63 \\
\hline $\mathrm{Mg}$ & 7549.62 & 3580.26 & 1072.33 & 113.77 & 1174.78 & 223.42 & 760.00 & 51.96 \\
\hline $\mathrm{Mn}$ & 425.31 & 291.70 & 26.65 & 4.82 & 33.33 & 12.80 & 20.00 & 0.00 \\
\hline $\mathrm{Na}$ & 762.77 & 635.17 & NA & NA & NA & NA & NA & NA \\
\hline $\mathrm{Ni}$ & 21.15 & 20.64 & 24.39 & 52.08 & 8.23 & 6.09 & 6.67 & 0.58 \\
\hline$P$ & 989.00 & 426.48 & 5373.91 & 552.84 & 5442.22 & 1043.25 & 4246.67 & 435.47 \\
\hline$S$ & 968.15 & 533.17 & 2861.52 & 272.27 & 3405.56 & 606.25 & 3513.33 & 320.36 \\
\hline $\mathrm{Si}$ & 1155.83 & 1073.93 & 293.17 & 149.69 & 445.33 & 208.39 & 337.33 & 18.61 \\
\hline $\mathrm{Sr}$ & 195.39 & 102.57 & 1.71 & 0.82 & 4.42 & 4.36 & 3.17 & 0.64 \\
\hline $\mathrm{Ti}$ & 816.54 & 1409.21 & $\mathrm{DL}$ & $\mathrm{DL}$ & 3.44 & 3.75 & 1.43 & 0.40 \\
\hline V & 62.15 & 46.82 & $\mathrm{DL}$ & $\mathrm{DL}$ & $\mathrm{DL}$ & $\mathrm{DL}$ & $\mathrm{DL}$ & $D L$ \\
\hline $\mathrm{Zn}$ & 63.85 & 25.55 & 333.76 & 56.60 & 429.33 & 110.35 & 270.67 & 36.91 \\
\hline $\mathrm{Zr}$ & 18.54 & 18.74 & $\mathrm{DL}$ & $\mathrm{DL}$ & $\mathrm{DL}$ & $\mathrm{DL}$ & $\mathrm{DL}$ & $\mathrm{DL}$ \\
\hline
\end{tabular}


Citation: Tigar BJ, Hursthouse AS. Applying Biogeochemistry to Identify the Geographic Origins of Insects-A Model Using Prostephanus truncatus. J Environ Stud. 2016;2(1): 9.

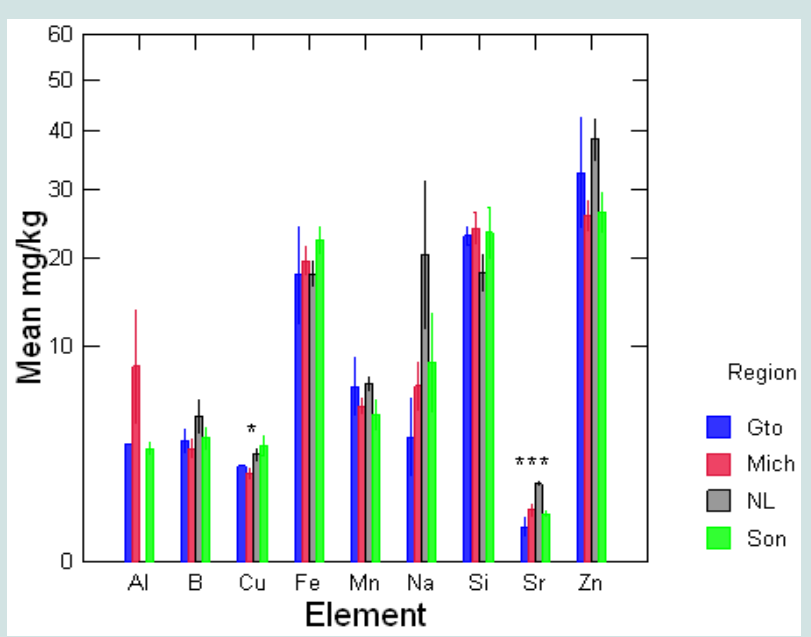

Figure 2: Mean mg/kg of $\mathrm{Al}, \mathrm{B}, \mathrm{Cu}, \mathrm{Fe}, \mathrm{Mn}, \mathrm{Na}, \mathrm{Si}, \mathrm{Si}$, and $\mathrm{Zn}$ in maize from different regions (elements at low concentrations). Error bars are standard error around the mean at 0.68 . Gto: Guanajuato; Mich: Michoacán; NL: Nuevo Léon; Son: Sonora.

Where ${ }^{*}$ and ${ }^{* * *}$ indicate $p \leq 0.05$ and $p \leq 0.005$ respectively Kruskal-Wallis test.

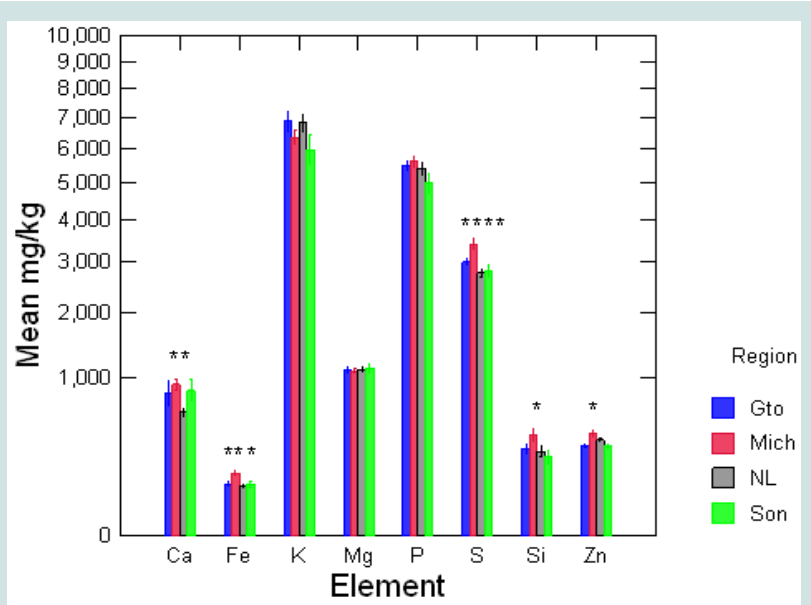

Figure 3: Mean concentration ( $\mathrm{mg} / \mathrm{kg}$ ) of $\mathrm{Ca}, \mathrm{Fe}, \mathrm{K}, \mathrm{Mg}, \mathrm{P}, \mathrm{S}, \mathrm{Si}$ and $\mathrm{Zn}$, elements detected in $P$. truncatus (high concentrations) reared on known maize in the lab by region, error bars are standard errors around the mean at 0.68. Gto: Guanajuato; Mich: Michoacán; NL: Nuevo Léon; Son: Sonora. Where *, **, ${ }^{* * *}$ and $* * *$ indicate $p \leq 0.05, p \leq 0.01, p \leq 0.005$ and $p \leq 0.00$ respectively Kruskal-Wallis test.

chemically screened in a Perkin-Elmer Optima 3000 ICP Spectrometer operating at default conditions, alongside reference samples and laboratory standards to ensure consistency of determination. Mean concentrations of analytes were taken from four readings off the calibration curve for each element.

\section{Sample interpretation and analysis}

Most elemental determinations of maize and beetles were skewed towards low concentrations and many remained non-normally distributed even after transformation (tested via a Shapiro Wilk's test where $p>0.005$ indicates normality, S2). Therefore to identify which multiple-elements varied significantly by location for each material tested, all elemental concentrations were analysed using a conservative non-parametric Kruskal-Wallis (Mann-Whitney U).
Analyses were performed using SYSTAT V13.1 with exact tests [47] to account for uneven sample sizes and occasional missing data points for samples where rarer elements were below DLs.

An LDA was used to classify $P$. truncatus and maize according to the geochemical origin of capture [18] or the origin of the maize that laboratory-reared insects were reared on. The region of capture or collection was used as the dependent categorical variable (insects reared on two commercially brought grains were excluded as they lack provenance data, S1). LDA assumes a normal distribution of data, therefore only elements above DLs showing significantly different concentrations according to origin in a Kruskal-Wallis test (S3) and a normal distribution after transformation ( $\mathrm{p}>0.005$ Shapiro Wilk's test, S2) were used as independent variables in the model. Stepwise LDA classification matrices were calculated with and without jackknifing, as the latter can adjust for overestimation when the case being classified is in the same classification matrix [48].

\section{Results}

\section{Elemental profiles of different materials}

Mean determinations $(\mathrm{mg} / \mathrm{kg})$ were highest in soils followed by insects, with maize having the lowest determinations of most elements (Table 1), with 14 elements above DL in all materials: Al, B, Ba, Ca, Fe, $\mathrm{K}, \mathrm{Mg}, \mathrm{Mg}, \mathrm{Mn}, \mathrm{P}, \mathrm{S}, \mathrm{Si}$, Sr and Zn. The high variation evident in Table 1 supports the assumption that soil, grain and insect background geochemistry show variations, and that the concentrations of different elements may vary according to the location or origin.

For ease of interpretation elements were grouped into high or low concentrations for each material tested. $\mathrm{Ca}, \mathrm{Fe}, \mathrm{K}, \mathrm{Mg}, \mathrm{P}, \mathrm{S}$ and $\mathrm{Si}$ were at high concentrations $(>1000 \mathrm{mg} / \mathrm{kg})$ in all materials, with high concentrations of $\mathrm{Al}, \mathrm{Na}$ and $\mathrm{Ti}$ in soils and of $\mathrm{Zn}$ in insects (Table 1). Elements at low concentrations fit the general definition of trace elements, occurring at $<100 \mathrm{mg} / \mathrm{kg}$ in the biological materials tested.

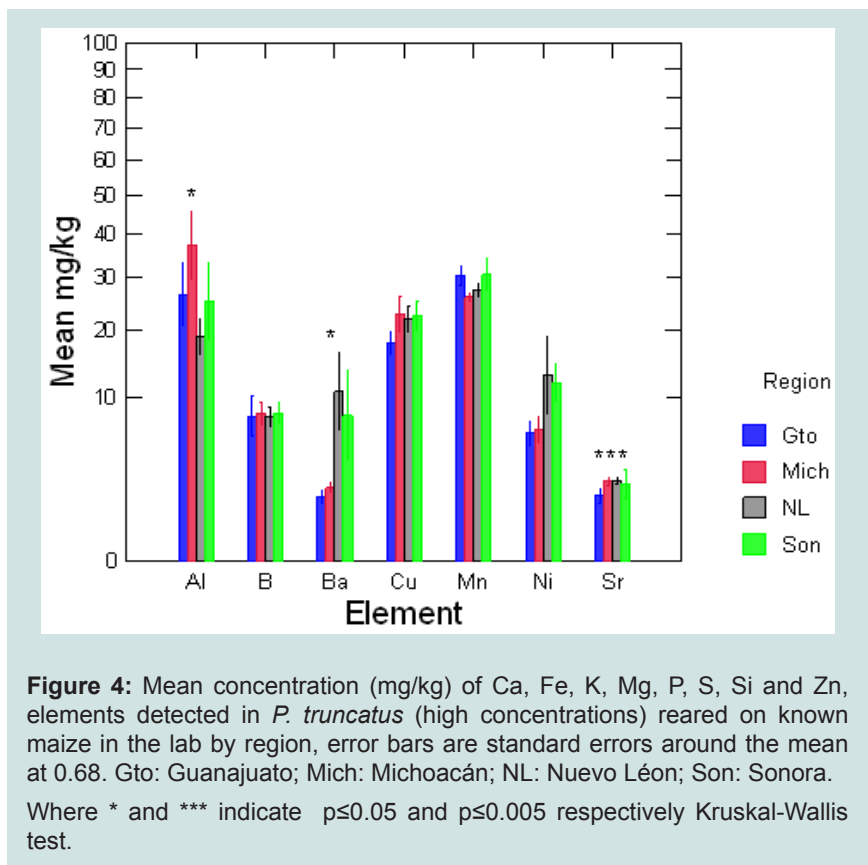


Citation: Tigar BJ, Hursthouse AS. Applying Biogeochemistry to Identify the Geographic Origins of Insects-A Model Using Prostephanus truncatus. J Environ Stud. 2016;2(1): 9.

Table 2: Transfer of selected elements from soil to plant product to insects with mean (Standard Deviation, SD) values from ICP-AES determinations of soil, maize and $P$. truncatus in $\mathrm{mg} / \mathrm{kg}$, and calculated mobility index (MI, shown in bold) for these elements between each trophic level.

\begin{tabular}{|c|c|c|c|c|c|}
\hline Element & $\begin{array}{c}\text { Soil } \\
\text { mean (SD) }\end{array}$ & $\begin{array}{c}\text { Maize } \\
\text { mean } \\
(\mathrm{SD})\end{array}$ & $\begin{array}{c}\text { MI } \\
\text { soil to } \\
\text { maize }\end{array}$ & $\begin{array}{l}P . \text { truncatus } \\
\text { mean (SD) }\end{array}$ & $\begin{array}{c}\text { MI } \\
\text { maize to } \\
P . \\
\text { truncatus }\end{array}$ \\
\hline $\mathrm{Cu}$ & $15.1(9.7)$ & $2.2(0.4)$ & $0.2(0.1)$ & $41.9(55.8)$ & $20.1(28.2)$ \\
\hline $\mathrm{Fe}$ & $\begin{array}{c}26248 \\
(14727)\end{array}$ & $18.3(5.8)$ & $0.0(0.0)$ & $107.3(12.6)$ & $6.5(2.4)$ \\
\hline $\mathrm{Zn}$ & $63.2(22.7)$ & $32.9(10.4)$ & $0.7(0.4)$ & $343.2(30.6)$ & $11.5(3.7)$ \\
\hline
\end{tabular}

Table 3: Results from the LDA classification matrix for percentage of correctly assigned lab-reared $P$. truncatus to four regions before and after Jackknifing using $\mathrm{Al}, \mathrm{Fe}, \mathrm{Sr}$ and $\mathrm{Zn}$ as independent variables.

\begin{tabular}{|l|l|l|}
\hline \multicolumn{1}{|c|}{ Region } & $\begin{array}{c}\text { Classification Matrix } \\
\text { \% correctly classified }\end{array}$ & $\begin{array}{c}\text { Jackknifed Classification } \\
\text { Matrix \% correctly classified }\end{array}$ \\
\hline Guanajuato & 82 & 73 \\
\hline Michoacán & 60 & 40 \\
\hline Nuevo Léon & 92 & 85 \\
\hline Sonora & 63 & 50 \\
\hline Total & 78 & 68 \\
\hline
\end{tabular}

\section{Elemental characterization of soil}

The mean and standard error of soil determinations of elements detected at high and low concentrations are shown in S3 and S4 respectively. The results seen in Table 1 suggest differences between samples collected in different regions particularly for $\mathrm{Al}, \mathrm{Ca}, \mathrm{K}, \mathrm{Sr}$ and V. As soil data were scant $(n=13)$ they only provide baseline information on Mexican soil profiles and allow the trophic transfer of elements above DL in all three materials to be traced from soil to grain and into an insect.

\section{Exploration of maize by origin}

Elemental profiles of maize by region are shown in Figures 1 and 2 (high and low concentrations respectively). A Kruskal-Wallis comparison between elemental concentrations in maize by region showed significant differences for $\mathrm{Cu}, \mathrm{S}$ and $\mathrm{Sr}$ according to region of origin (S5).

\section{Exploration elemental profiles for $P$. truncatus by origin}

Elemental profiles of $P$. truncatus of known origin or raised on maize of known origin were explored by region, with results at high and low concentration shown in Figures 3 and 4. A Kruskal-Wallis test showed significant differences between concentrations of $\mathrm{Al}, \mathrm{Ba}$, $\mathrm{Ca}, \mathrm{Fe}, \mathrm{S}, \mathrm{Si}, \mathrm{Sr}$, Ti and $\mathrm{Zn}$ according to origin (S6).

Only two elements, $\mathrm{S}$ and Sr, were significantly different according to their origins in the Kruskal-Wallis tests for P. truncatus and for maize (S5 \& S6, Figures 2-4).

\section{Elemental transfer from soils to maize to insects}

A MI was estimated for $\mathrm{Cu}, \mathrm{Fe}$ and $\mathrm{Zn}$ which were the only elements above DLs in all materials tested. These were followed up the food chain into P. truncatus (Table 2). Relative concentrations of elements were lower in maize than soil whilst they were higher for insects than the maize they had consumed, with values for $\mathrm{Cu}, \mathrm{Fe}$ and $\mathrm{Zn}$ at 20, 6.5 and 11.5 times (respectively) the concentration of maize. These are typical of the differences between crop plants and soils, and crop plants and insects $[42,43,46]$ Relative Fe concentrations were highest in insects, and all three elements are potential intrinsic markers.

\section{Linear Discriminate Analysis to classify the origin of P.truncatus and maize using elemental profiling}

Following the Kruskal-Wallis (S6) and Shapiro Wilk's tests (S2) on elemental determinations of $P$. truncatus four elements, $\mathrm{Al}, \mathrm{Fe}$, $\mathrm{Sr}$ and $\mathrm{Zn}$ were identified as independent variables with a normal distribution. These were used in an LDA to classify insects according to their region of capture or of the maize they were reared on. The first LDA used data from laboratory-reared beetles with origin of maize indicating region, and the second LDA used field-captured beetles collected from a limited set of locations (regions) because some pheromone-baited flight traps did not catch any insects.

The classification matrix for lab-reared $P$. truncatus correctly assigned $78 \%$ of the beetles to the region where maize (their exclusive diet) had been collected (Table 3). This was highest for Nuevo Léon (92\%) and Guanajuato (82\%) and lowest for Sonora (63\%) and Michoacán (60\%). More conservative classification estimates obtained after jackknifing lowered the overall success rate to $68 \%$ (Table 3) with similarly lower success rates when assigning beetles by region, and this was particularly poor for Michoacán (40\%). Canonical score 1 explained $>89 \%$ of the correlations and $>93 \%$ of the data dispersal, increasing to $>98 \%$ with the addition of Factor 2 (Table 4). The Eigen value for canonical score 1 was 4.169 , with scores 2 and 3 contributing little compared with score 1 . Overall results show a Wilk's $\lambda$ of 0.146 (with 12, $79 \mathrm{df}$ ) with an approximate $F$ ratio of 7.096 at $\mathrm{P}<0.001$ (Table 4).

Canconical scores 1 and 2 are plotted in Figure 5 and show

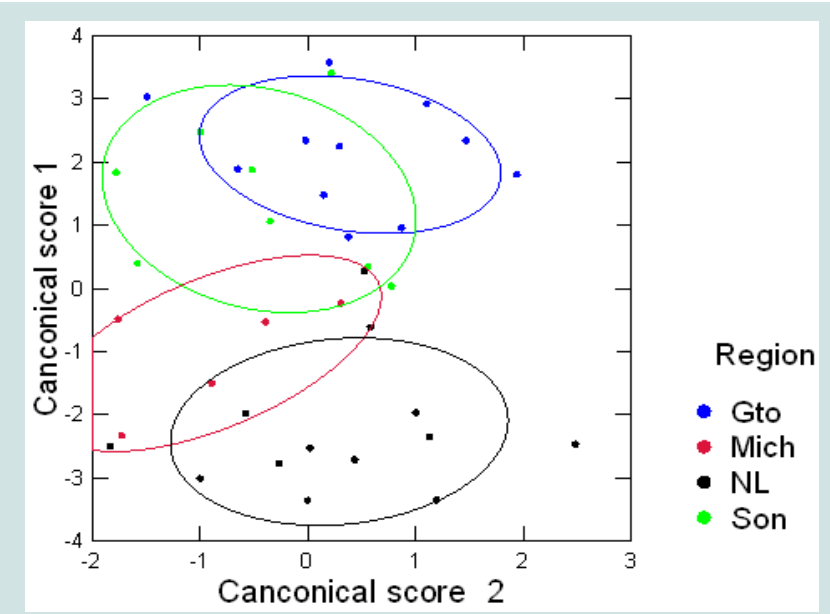

Figure 5: Plot of canonical scores 1 and 2 classifying laboratory-reared $P$. truncatus by region. The canconical scores arose from an LDA model using $\mathrm{Al}, \mathrm{Fe}, \mathrm{Sr}$ and $\mathrm{Zn}$ as predictor variables for region and explain $>98 \%$ of the data dispersal. The colours of the ellipses outline the distribution around $68 \%$ of the data points, empathizing the correctly classified data points for each region and the separation or overlap between regions.

Gto: Guanajuato; Mich: Michoacán; NL: Nuevo Léon; Son: Sonora. 
Citation: Tigar BJ, Hursthouse AS. Applying Biogeochemistry to Identify the Geographic Origins of Insects-A Model Using Prostephanus truncatus. J Environ Stud. 2016;2(1): 9.

ISSN: $2471-4879$

Table 4: LDA canconical scores and Eigen values using $\mathrm{Al}, \mathrm{Fe}, \mathrm{Sr}$ and $\mathrm{Zn}$ to classify lab-reared $P$. truncatus by region.

\begin{tabular}{|l|l|l|l|}
\hline $\begin{array}{l}\text { Canconical } \\
\text { score }\end{array}$ & Eigenvalues & $\begin{array}{l}\text { Canonical } \\
\text { Correlations }\end{array}$ & $\begin{array}{l}\text { Cumulative } \\
\text { Proportion of } \\
\text { Total Dispersion }\end{array}$ \\
\hline 1 & 4.169 & 0.898 & 0.931 \\
\hline 2 & 0.252 & 0.449 & 0.987 \\
\hline 3 & 0.057 & 0.233 & 1.000 \\
\hline
\end{tabular}

Table 5: Results from the LDA classification matrix for percentage of correctly assigned field-captured $P$. truncatus to three regions before and after Jackknifing using $\mathrm{Al}, \mathrm{Fe}, \mathrm{Sr}$ and $\mathrm{Zn}$ as independent variables.

\begin{tabular}{|l|l|l|}
\hline \multicolumn{1}{|c|}{ Region } & $\begin{array}{c}\text { Classification Matrix } \\
\% \text { correctly classified }\end{array}$ & $\begin{array}{l}\text { Jackknifed Classification } \\
\text { Matrix \% correctly classified }\end{array}$ \\
\hline Michoacán & 100 & 85 \\
\hline Nuevo Léon & 0 & 0 \\
\hline Sonora & 100 & 67 \\
\hline Total & 94 & 76 \\
\hline
\end{tabular}

Table 6: LDA results using $\mathrm{Al}, \mathrm{Fe}, \mathrm{Sr}$ and $\mathrm{Zn}$ to classify field-captured $P$. truncatus by region.

\begin{tabular}{|l|l|l|l|}
\hline Factor & Eigenvalues & $\begin{array}{c}\text { Canonical } \\
\text { Correlations }\end{array}$ & $\begin{array}{c}\text { Cumulative Proportion of Total } \\
\text { Dispersion }\end{array}$ \\
\hline 1 & 3.083 & 0.869 & 0.966 \\
\hline 2 & 0.108 & 0.312 & 1.000 \\
\hline
\end{tabular}

Note: Samples were limited by availability, in some areas very few were captured.

that the LDA for laboratory-reared $P$. truncatus gave complete separation between beetles from two regions, Guanajuato and Nuevo Léon, as well as Guanajuato and Michoacán, and almost complete separation between beetles from Sonora and Nuevo Léon. However, the distribution of Sonoran beetles overlapped with those from Guanajuato and some of the Michoacán distributions, with further overlap between beetles from Michoacán and Nuevo Léon.

Only limited data were obtained for field-captured insects, none were captured from Guanajuato and only a couple from Nuevo Léon limiting the regions in the model. The classification correctly assigned $94 \%$ of the beetles to one of the three regions where they had been collected (Table 5) with 100\% success for both Michoacán and Sonora, but zero for Nuevo Léon. After jackknifing the overall success rate was $76 \%$ with slightly lower success rates for assigning beetles to the two regions mentioned above.

The canonical score 1 for field-captured P. truncatus explained $86 \%$ of the correlations and $96 \%$ of the data dispersal (Table 6). Data for scores 1 and 2 are plotted in Figure 6 and show complete separation between beetles from Michoacán and Sonora reflecting their $100 \%$ classification rates. The Nuevo Léon samples overlapped with the distribution of Michoacán beetles. The Eigen value for Canonical score 1 was 4.169 , with lower contributions from scores 2 and 3. Wilk's $\lambda$ was 0.221 (with $8,22 \mathrm{df}$ ) with an approximate $\mathrm{F}$ ratio of 3.098 at $\mathrm{P}=0.017$.

A similar LDA was carried out on the maize P. truncatus was reared on for comparison. However, $\mathrm{Al}$ was excluded as it was below DL in many maize samples. The classification correctly assigned $77 \%$ of the maize to the geochemical origin where it had been collected (Table 7) with $100 \%$ success for both Guanajuato and Nuevo Léon Sonora, $80 \%$ for Sonora and lower for Michoacán. After jackknifing the overall success rate was $64 \%$ with reduced rates for assigning maize to region except for Nuevo Léon.

The canonical score 1 for maize explained $89 \%$ of the correlations and $74 \%$ of the data dispersal (Table 8 ). Data for scores 1 and 2 are plotted in Figure 7 and show complete separation between maize from Guanajuato, Nuevo Léon and Sonora reflecting their high classification rates. The Michoacán data show a wider spread and completely contain the Sonoran data within them. The Eigen value for Canonical score 1 was 3.731, with lower contributions from scores 2 and 3.

\section{Discussion}

We present a robust technique based on ICP-AES that identified a combination of elements able to determine the geographic origin of an insect or the maize it was reared on with a high degree of success. The methodology was sensitive enough to detect background levels of a range of elements including some trace elements in insects, grain and soil, and added to knowledge of natural background geochemistry of animals and plants. It produced multi-elemental profiles that could distinguish between materials collected from different locations, although the elements selected varied according to the material analysed. This is to be expected since factors including background concentration and sample weight can influence whether or not a particular element is detected. In addition, the ease of extraction and mobility of elements are likely to vary between materials $[5,19,20,42,43]$.

For our study species $\mathrm{Al}, \mathrm{Fe}, \mathrm{Sr}$ and $\mathrm{Zn}$ concentrations correctly classified most laboratory-reared and field-caught $P$. truncatus according to the geochemistry of the location where they or their food had been collected. Bi-plots of canonical scores from this LDA

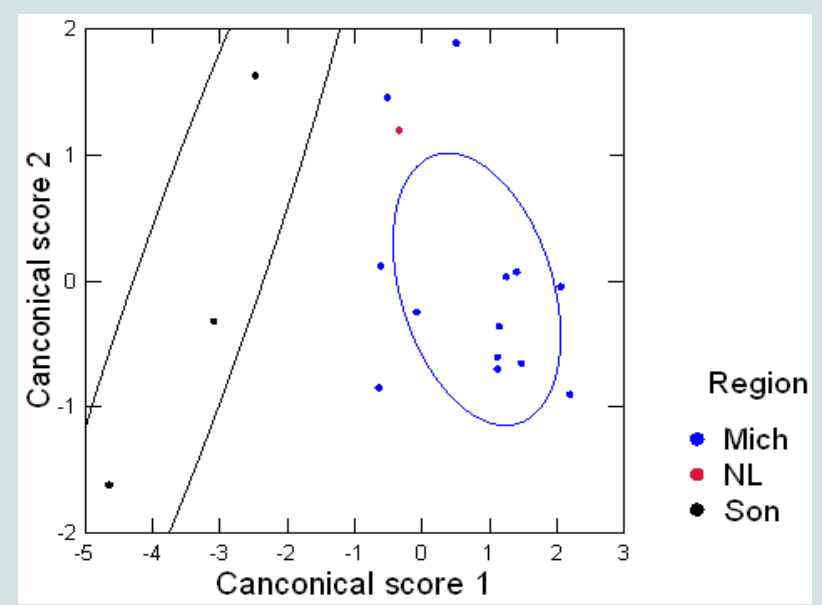

Figure 6: Plot of canonical scores 1 and 2 classifying field-captured $P$. truncatus by region. The canconical scores arose from an LDA model using $\mathrm{Al}, \mathrm{Fe}, \mathrm{Sr}$ and $\mathrm{Zn}$ as predictor variables for region and explain $100 \%$ of the data dispersal. The colour of the ellipses outlines the distribution around $68 \%$ of the data points (end not visible for Sonoran data), empathizing the clustering of correctly classified data points for each region and the separation between regions.

Mich: Michoacán; NL: Nuevo Léon; Son: Sonora. 
Citation: Tigar BJ, Hursthouse AS. Applying Biogeochemistry to Identify the Geographic Origins of Insects-A Model Using Prostephanus truncatus. J Environ Stud. 2016;2(1): 9.

Table 7: Results from the LDA classification matrix for percentage of correctly assigned maize to four regions before and after Jackknifing using $\mathrm{Fe}, \mathrm{Sr}$ and $\mathrm{Zn}$ as independent variables.

\begin{tabular}{|l|l|l|}
\hline \multicolumn{1}{|c|}{ Region } & \multicolumn{1}{|c|}{$\begin{array}{c}\text { Classification Matrix } \\
\% \text { correctly classified }\end{array}$} & $\begin{array}{c}\text { Jackknifed Classification } \\
\text { Matrix \% correctly classified }\end{array}$ \\
\hline Guanajuato & 100 & 75 \\
\hline Michoacán & 43 & 29 \\
\hline Nuevo Léon & 100 & 100 \\
\hline Sonora & 80 & 60 \\
\hline Total & 77 & 64 \\
\hline
\end{tabular}

Table 8: LDA results using $\mathrm{Fe}, \mathrm{Sr}$ and $\mathrm{Zn}$ to classify maize by region.

\begin{tabular}{|l|l|l|l|}
\hline Factor & Eigenvalues & $\begin{array}{c}\text { Canonical } \\
\text { Correlations }\end{array}$ & $\begin{array}{c}\text { Cumulative Proportion } \\
\text { of Total Dispersion }\end{array}$ \\
\hline 1 & 3.731 & 0.888 & 0.743 \\
\hline 2 & 1.264 & 0.747 & 0.994 \\
\hline 3 & 0.029 & 0.169 & 1.000 \\
\hline
\end{tabular}

showed complete separation between some locations, and where these overlapped this mirrored the lower percentage of correct classifications, particularly for Michoacán. Similar patterns were seen in the LDA for maize, which showed complete separation for three regions although those from Sonora were entirely within those of Michoacán. LDAs based on elemental concentrations have been used to determine the geolocation of other invertebrates [18,49] with $\mathrm{V}, \mathrm{Mn}, \mathrm{Fe}, \mathrm{Mo}, \mathrm{Se}, \mathrm{Cd}, \mathrm{Ce}$ and Nd concentrations classifying $>92 \%$ of the migratory pest RBPH to one of seven Chinese locations [18], and $\mathrm{Cd}, \mathrm{Cu}, \mathrm{Fe}, \mathrm{Pb}$ and $\mathrm{Zn}$ concentrations classifying fresh water invertebrates according to the elevated levels they had accumulated in contaminated lakes [48].

The LDA for $P$. truncatus was restricted to independent variables with a normal distribution, although the non-parametric tests suggest that other elements may be intrinsic markers linked to the origin of an organism including $\mathrm{Ba}, \mathrm{Ca}, \mathrm{S}$, and $\mathrm{Si}$ for insects, and $\mathrm{Cu}, \mathrm{S}$ and $\mathrm{Sr}$ for maize. Older studies suggest that markers can vary with study species and host-specificity, as well as life-stage. A Principal Components Analysis (PCA) for the aphids R. padi and Metapolodium dirhodum used $\mathrm{Al}, \mathrm{Fe}$ and $\mathrm{Mn}$, and $\mathrm{Al}, \mathrm{Ca}$ and $\mathrm{Cl}$ respectively to distinguish whether they had been reared on oats or wheat [32], whilst $S, K$ and $\mathrm{Cl}$ distinguished between $M$. dirhodum alates (winged, sexually reproductive adults) and apterae (wingless asexually reproductive adults), suggesting that apterae were more readily categorised by hostplant soil geochemistry than were alates [33]. Whilst for polyphagous moths, distinctive chemoprints based on $\mathrm{Zn}, \mathrm{Si}, \mathrm{Al}, \mathrm{Fe}, \mathrm{Cu}, \mathrm{Mn}, \mathrm{Ni}$ and $\mathrm{Cr}$ showed better association with the choice of larval hostplant than the soil chemistry of plants [34]. The LDA for laboratoryreared $P$. truncatus classified insects according to their geochemical profile when reared exclusively on maize, eliminating variation due to alternative natal hosts. Whilst the LDA for field-captured insects suggests that the short sampling period helped restrict capture to young adults dispersing from their natal hosts in nearby agricultural areas $[44,45]$.

Holder et al. used multivariate models to determine the origin of an invasive insect, $H$. armigera. Concentrations of trace elements ( $\mathrm{Sr}$, $\mathrm{Cs}, \mathrm{Ba}$ and $\mathrm{Pb})$ combined with stable isotopes $\left(\delta^{2} \mathrm{H},{ }^{87} \mathrm{Sr} /{ }^{86} \mathrm{Sr},{ }^{208} \mathrm{~Pb} /{ }^{206} \mathrm{~Pb}\right.$ and ${ }^{208} \mathrm{~Pb} /{ }^{207} \mathrm{~Pb}$ ) gave the most accurate models and determined origin of about $73 \%$ insects [3]. They also report differences between years and sex, and emphasise the importance of the controlled rearing of mobile herbivores on known host-plants, grown in soils of known and differing geochemistry, in order to validate multi-elemental models used to classify field samples of unknown origin.

There are some limitations to our study. Firstly, it was necessary to use a pooled sample of 10 insects for each determination which may lower the classification rate, particularly where geochemistry shows high local variation. However, multivariate models have the capacity to reveal where the majority of a population originates from, as demonstrated by the LDA for RBPH which required 350 insects per determination whilst producing sufficient resolution to distinguish between insects captured at seven geographical locations where this highly mobile species had been sampled [18].

Using 10 beetles per determination helped to maximise the number of samples we could analyse consistently and since it was a pooled value this reduced the influence of the occasional field insect from different food sources or from a host grown on a locally varying geochemistry. It is also possible that some elements detected are involved in metabolic processes, although the exact role of trace elements and minerals is poorly known in most insects [50,51]. However, using multivariate models which are not dependent on single elements in isolation helps to reduce the effect of each element including those involved in regulatory processes, which are likely to differ between insects and their foods. Future work would also benefit from further investigating soil-plant relationships based on background elemental levels, since these often regulate uptake for trace elements and transfer factors work as consistent values even when soil content varies [5].

In common with other studies that validate field data on elemental loads with controlled rearing experiments [3,31-35], we reared

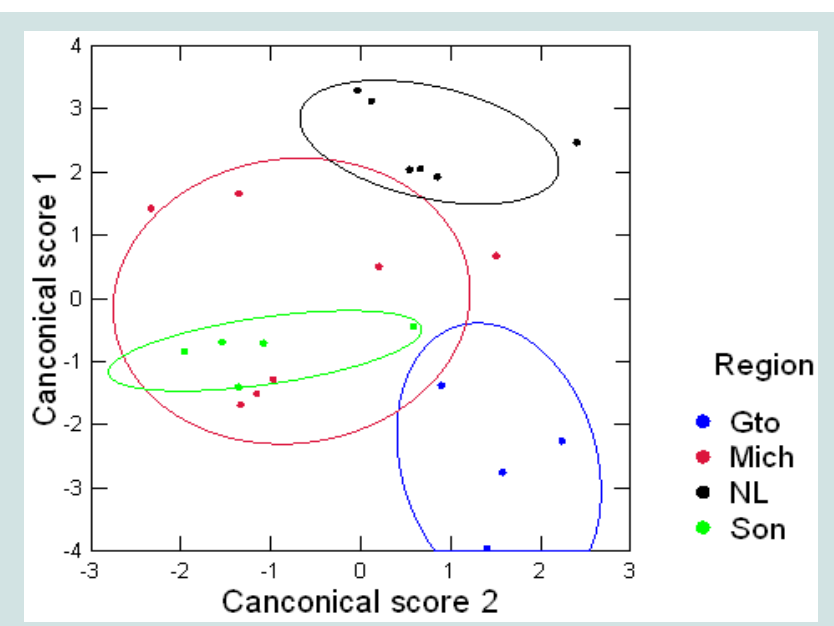

Figure 7: Plot of canonical scores 1 and 2 classifying maize by region. The canconical scores arose from an LDA model using $\mathrm{Fe}, \mathrm{Sr}$ and $\mathrm{Zn}$ as predictor variables for region and explain $99 \%$ of the data dispersal. The colour of the ellipses outlines the distribution around $68 \%$ of the data points, empathizing the clustering of correctly classified data points for each region and the separation between regions.

Gto: Guanajuato; Mich: Michoacán; NL: Nuevo Léon; Son: Sonora Gto: Guanajuato; Mich: Michoacán; NL: Nuevo Léon; Son: Sonora. 
Citation: Tigar BJ, Hursthouse AS. Applying Biogeochemistry to Identify the Geographic Origins of Insects-A Model Using Prostephanus truncatus. J Environ Stud. 2016;2(1): 9.

ISSN: $2471-4879$

P. truncatus on maize of different origins for one generation. This reflects the assimilation of background levels of elements up the food chain, from egg to adult. It assumes that elemental profiles are not likely to be influenced by changes in geochemistry resulting from adult feeding activities. This is a poorly known topic but may explain differences between the regional elemental loads of laboratory reared and field-caught insects, and is a topic which would benefit from further research. In addition, collecting maize direct from farmers meant we could not control for the variety of maize, so any unknown differences in the assimilation of elements between maize varieties was not accounted for. It is also possible that profiles of field beetles differed if they had fed on alternative food sources from maize.

The soil samples were of limited value but give data on background variations in Mexico, and support the current interest in regional geochemical surveys such as those of agricultural soils [52] and the transfer of elements into human food plants including maize $[42,43]$. Future studies would benefit from controlled rearing of both insects and their host plants under experimental conditions. This would facilitate more rigorous sampling of soils, host plants and insects, and transfer up the food chain, and help provide data on the transfer of natural levels of multiple elements. Such data also help by enabling GIS modelling approaches where combinations of elemental concentrations detected in biological materials are linked to location data, this continues to be widely applied in the isoscape approach for $\mathrm{H}$ and $\mathrm{O}$ isotopes [15].

Intrinsic geochemical markers have great potential for tracking animals, particularly invasive species which are an increasing cause for concern, both in terms of agricultural and medical pests, but also destructive species that out compete native species and threaten a wide range of taxa and ecosystems [53,54]. Although detection methods have continued to develop since we completed this study, these results emphasise that meaningful data can be obtained using less sensitive methods such as ICP-AES. As atomic spectroscopy techniques become more widely available and more sensitive; their ability to determine naturally occurring levels of elements will increase. Therefore elemental profiling can be used to identify the origin of organisms that move from one geochemically unique environment to another with recent studies suggesting that resolution improves when specific elemental concentrations, particularly the rarer ones, are combined with other intrinsic markers including stable isotopes and molecular genetics into multivariate models $[3,18]$.

\section{References}

1. Pedigo LP, Buntin GD (1993) Handbook of sampling methods for arthropods in agriculture. Taylor \& Francis, CRC Press, pp. 736.

2. Nansen C, Meikle WG, Tigar B, Harding S, Tchabi A (2004) Nonagricultural hosts of Prostephanus truncatus (Coleoptera: Bostrichidae) in a West African forest. Ann Entomol Soc Am 97: 481-491.

3. Holder PW, Armstrong K, Van Hale R, Millet MA, Frew R, et al. (2014) Isotopes and trace elements as natal origin markers of Helicoverpa armigera-an experimental model for biosecurity pests. PLoS One 9: e92384.

4. Kabata-Pendias A (2010) Trace elements in soils and plants, fourth edition. Taylor \& Francis, CRC Press, USA

5. Hursthouse AS (2001) The relevance of speciation in the remediation of soils and sediments contaminated by metallic elements--an overview and examples from Central Scotland, UK. J Environ Monit 3: 49-60.
6. Janssen MP, Hogervorst R (1993) Metal accumulation in soil arthorpods in relation to micro-nutrients. Environ Pollut 79: 181-189.

7. Lindqvist $L$ (1988) Transport of cadmium from herbs to insects in a terrestrial environment. Entomologisk Tidskrift 4: 119-122.

8. Andrzejewska L, Czarnowksa K, Matel B (1991) Distribution of heavy metal pollution in plants and herbivorous Spodoptera littoralis L. Iepidoptera. Ekologia Polska 38: 185-200.

9. Zhang Z, Song X, Wang Q, Lu X (2012) Cd and Pb contents in soil, plants and grasshoppers along a pollution gradient in Huludao City, Northeast China. Biol Trace Elem Res 145: 403-410.

10. Robinson GR Jr., Sibrell PL, Boughton CJ, Yang LH (2007) Influence of soil chemistry on metal and bioessential element concentrations in nymphal and adult periodical cicadas (Magicicada spp.). Sci Total Environ 374: 367 378.

11. Kazimirova M, Ortel J (2000) Metal accumulation by Ceratitis capitata (Diptera) and transfer to the parasitic wasp Coptera occidentalis (Hymenoptera). Environ Toxicol Chem 19: 1822-1829.

12. Risley LS (1990) Relationships among potassium, calcium and trace elements in tree leaves and associated with canopy arthropods. J Entomol Sci 25: 439-449.

13. Kump P, Necemer M, Snajder J (1996) Determination of trace elements in bee honey, pollen and tissue by total reflection and radioisotope X-ray fluorescence spectrometry. Spectrochim Acta Part B: At Spectrosc 51: 499507.

14. Rubenstein DR, Hobson KA (2004) From birds to butterflies: animal movement patterns and stable isotopes. Trends Ecol Evol 19: 256-263.

15. West JB, Bowen GJ, Cerling TE, Ehleringer JR (2006) Stable isotopes as one of nature's ecological recorders. Trends Ecol Evol 21: 408-414.

16. Lindqvist $L$ (1992) Accumulation of cadmium, copper and zinc in 5 species of phytophagous insects. Environ Entomol 21: 160-163.

17. Laskowski R, Bednarska AJ, Spurgeon D, Svendsen C, van Gestel CA (2010) Three-phase metal kinetics in terrestrial invertebrates exposed to high metal concentrations. Sci Total Environ 408: 3794-3802.

18. Peng Q, Tang QY, Wu JL, Miao QL, Cheng JA (2012) Determining the geographic origin of the brown planthopper, Nilaparvata lugens, using trace element content. Insect Sci 19: 21-29.

19. Akey DH, Burns DW (1991) Analytical consideration and methodologies for elemental determinations in biological samples. Southwest Entomol Suppl 14: $25-36$

20. Beavington F (2001) Pioneer studies in trace element contamination of the food chain: disregard of prior work risks reinventing the wheel. J Sci Food Agric 81: 155-160.

21. Choy ES, Gauthier M, Mallory ML, Smol JP, Douglas MS, et al. (2010) An isotopic investigation of mercury accumulation in terrestrial food webs adjacent to an Arctic seabird colony. Sci Total Environ 408: 1858-1867.

22. Kozlov MV, Haukioja E, Kovnatsky EF (2000) Uptake and excretion of nicke and copper by leaf-mining larvae of Eriocrania semipurpurella (Lepidoptera: Eriocraniidae) feeding on contaminated birch foliage. Environ Pollut 108: 303310.

23. Winder L, Merrington G, Green I (1999) The tri-trophic transfer of Zn from the agricultural use of sewage sludge. Sci Total Environ 229: 73-81.

24. Gal J, Markiewicz-Patkowska J, Hursthouse A, Tatner P (2008) Metal uptake by woodlice in urban soils. Ecotoxicol Environ Saf 69: 139-149.

25. Atrouse OM, Oran SA, Al-Abbadi SY (2004) Chemical analysis and identification of pollen grains from different jordanian honey samples. Int $\mathrm{J}$ Food Sci Tech 39: 413-417.

26. Pilgrim TS, Watling RJ, Grice K (2010) Application of trace element and stable isotope signatures to determine the provenance of tea (Camellia sinensis) samples. Food Chem 118: 921-926.

27. Ariyama K, Shinozaki M, Kawasaki A (2012) Determination of the geographic 
Citation: Tigar BJ, Hursthouse AS. Applying Biogeochemistry to Identify the Geographic Origins of Insects-A Model Using Prostephanus truncatus. J Environ Stud. 2016;2(1): 9 .

ISSN: $2471-4879$

origin of rice by chemometrics with strontium and lead isotope ratios and multielement concentrations. J Agric Food Chem 60: 1628-1634.

28. Monahan FJ, Moloney AP, Osorio MT, Röhrle FT, Schmidt O, et al. (2012) Authentication of grass-fed beef using bovine muscle, hair or urine. Trends Food Sci Technol 28: 69-76.

29. Aggarwal J, Habicht-Mauche J, Juarez C (2008) Application of heavy stable isotopes in forensic isotope geochemistry: A review. Appl Geochem 23: 26582666.

30. Marra PP, Dove CJ, Dolbeer R, Faridah Dahlan N, Heacker M, et al. (2009) Migratory Canada geese cause crash of US Airways Flight 1549. Front Ecol Environ 7: 297-301.

31. Bowden J, Digby PG, Sherlock PL (1984) Studies of elemental composition as a biological marker in insects. 1 . The influence of soil type and host-plant on elemental composition of Noctua pronuba(L) (Lepidoptera: Noctuidae). B Entomol Res 74: 207-225.

32. Bowden J, Sherlock PL, Digby PG, Fox JS, Rhodes JA (1985) Studies of elemental composition as a biological marker in insects. II. The elemental composition of apterae of Rhopalosiphon padi (L.) and Metapolophium dirhodum (Walker) (Hemiptera: Aphididae) from different soils and hostplants. B Entomol Res 75: 107-120.

33. Bowden J, Sherlock PL, Digby PG (1985) Studies of elemental composition as a biological marker in insects. III. Comparison of apterous and alate cerea aphids, especially Rhopalosiphum padi (L.) (Hemiptera: Aphididae), from oats and wheat, and from oats infected with or free from barley yellow dwar virus. B Entomol Res 75: 477-488.

34. Sherlock PL, Bowden J, Digby PG (1985) Studies of elemental composition as a biological marker in insects. IV. The influence of soil type and hostplant on elemental composition of Agrotis segetum (Denis \& Schiffermuller) (Lepidoptera: Noctuidae). B Entomol Res 75: 675-687.

35. Sherlock PL, Bowden J, Digby PG (1986) Studies of elemental composition as a biological marker in insects. $V$. The elemental composition of Rhophalosiphon padi (L.) (Hempietra: Aphididae) from Prunus padus at different localities. B Entomol Res 76: 621-632.

36. Burns DW, Parsons ML, Herbaugh LL, Staten RT (1985) The migrating weevil. A challenge for ICP-AES and chemometrics. Anal Chem 57: 1048A-1052A.

37. Ethier DM, Kyle CJ, Nocera JJ (2014) Tracking animal movement by comparing trace element signatures in claws to spatial variability of elements in soils. Sci Total Environ 468-469: 699-705.

38. Schallhart N, Wallinger C, Juen A, Traugott M (2009) Dispersal abilities of adult click beetles in arable land revealed by analysis of carbon stable isotopes. Agric Forest Entomol 11: 333-339.

39. Tigar B, Waldron S (2003) Using new tools to track the larger grain borer, Prostephanus truncatus (Horn) (Coleoptera: Bostrichidae). In: Credland PF, Armitage DM, Bell CH, Cogan PM, Highley E (Eds). Advances in stored product protection. Proceedings of the 8th international working conference on stored product protection, York, UK, pp. 396-401.

40. Mahroof RM, Phillips TW (2012) Use of macro and trace elements as biological markers in the lesser grain borer, Rhyzopertha dominica (F.) (Coleoptera: Bostrichidae). J Stored Prod Res 48: 126-131.

41. Hodges RJ (1986) The biology and control of Prostephanus truncatus (Horn) (Coleoptera: Bostrichidae) -A destructive storage pest with an increasing range. J Stored Prod Res 22: 1-14.

42. Dickinson N, Rankin J, Pollard M, Maleta K, Robertson C, et al. (2014) Evaluating environmental and social influences on iron and zinc status of pregnant subsistence farmers in two geographically contrasting regions of Southern Malawi. Sci Total Environ 500-501: 199-210.

43. Joy EJ, Broadley MR, Young SD, Black CR, Chilimba AD, et al. (2015) Soi type influences crop mineral composition in Malawi. Sci Total Environ 505: 587-595.

44. Helbig J, Laborious GA, Schulz FA (1992) Investigations on the distance of trapping activity of the synthetic pheromone "trunc-call $(1+2)$ of Prostephanus truncatus (Horn) (Col., Bostrichidae) on its predator Teretriosoma nigrescens Lewis (Col., Histeridae). J Appl Entomol 113: 425-429.

45. Fadamiro HY, Wyatt TD (2008) Factors influencing response of flying Prostephanus truncatus to its male-produced aggregation pheromone. Physiol Entomol 21: 179-187.

46. Prince SP, Senthilkumar P, Subburam V (2001) Mulberry-silkworm food chain--a templet to assess heavy metal mobility in terrestrial ecosystems. Environ Monit Assess 69: 231-238.

47. SYSTAT (2009) Try SYSTAT 13 today. SYSTAT Software Inc. CA, USA.

48. Engleman L (2009) Discriminant analysis. SYSTAT 13 Statistics I, SYSTAT Software Inc, Chicago, USA, pp. 403-464.

49. Fialkowski W, Rainbow PS (2006) The discriminatory power of two biomonitors of trace metal bioavailabilities in freshwater streams. Water Res 40: $1805-1810$

50. Merrington G, Miller D, McLaughlin MJ, Keller MA (2001) Trophic barriers to fertilizer $\mathrm{Cd}$ bioaccumulation through the food chain: a case study using a plant--insect predator pathway. Arch Environ Contam Toxicol 41: 151-156.

51. Nation JL (2008) Insect physiology and biochemistry, ( $2^{\text {nd }}$ edn). In: Taylor \& Francis, CRC Press.

52. Reimann C, Siewers U, Tarvainen T, Bityukova L, Eriksson J, et al (2003) Agricultural Soils in Northernn Europe: a geochemical atlas. E. Schweizerbart'sche Verlagsbuchhandlung, Germany.

53. Clavero M, García-Berthou E (2005) Invasive species are a leading cause of animal extinctions. Trends Ecol Evol 20: 110.

54. Crowl TA, Crist TO, Parmenter RR, Belovsky G, Lugo AE (2008) The spread of invasive species and infectious disease as drivers of ecosystem change. Front Ecol Environ 6: 238-246.

\section{Acknowledgements}

We thank Guy Wiltshire for ICP-AES determinations and advice on sample preparation. We are grateful to all our Mexican collaborators for support in the field: M en C Miguel Najerra Rincon Najera (Centro Nacional de Investigación Para Produccion Sostenible, Morelia, Mexico), Dr. Francisco Wong Corral (Universidad de Sonora, Hermosillo, Mexico), Dr Josue Leos Martinez and Adriana Legorreta Millàn, (Universidad de Nuevo Léon, Monterrey, Mexico) and Dr Mario Ramirez Martinez (Almacenadora Mercader S.A., Guadalajara). We are indebted to Mexican farmers for access to their maize and fields for sample collection. This work was made possible by a NERC New Investigators' Scheme Award to Barbara Tigar (number NER/ M/S/2001/00122). Special thanks to Prof Roger McLean for support at University of the West of Scotland and Dr Rick Hodges (University of Greenwich) for founder cultures of $P$. truncatus. We thank two anonymous reviewers for their constructive comments which helped us to improve the quality of our article. 